\title{
Maximum likelihood estimates of gene frequencies and racial admixture in Apis mellifera L. (Africanized honeybees)
}

\author{
JORGE A. LOBO \& HENRIQUE KRIEGER* \\ Department of Genetics, Instituto Oswaldo Cruz, Cx. Postal 926, 20010 Rio de Janeiro, RJ, Brazil
}

\begin{abstract}
In order to obtain estimates of gene frequencies and other genetic parameters in Apis mellifera, samples are usually obtained from groups of haploid male (drones) and sterile female (workers) offspring, each group being descended from a multiply-mated single queen. A probabilistic model of segregation is presented which allows for maximum-likelihood estimates of genetic parameters in the reproductive individuals using the genotypic segregations of workers and drones from different colonies. Marginal probabilities of these segregations are calculated for each queen genotype by assuming a Dirichlet distribution for the fertilization frequencies of the different male alleles stored in the spermathecae. Estimates of gene frequencies and racial proportions in Africanized honey bees from different localities in Brazil and Central America reveal geographical heterogeneity in these parameters, possibly as a result of different levels of gene flow from European races.
\end{abstract}

Keywords: Africanized honeybees, gene frequencies, genetic structure, migration, polymorphisms, racial admixture.

\section{Introduction}

Isoenzyme and RFLP analysis in Apis mellifera have revealed a number of polymorphic markers with potential applications to different kinds of population studies (Sylvester, 1986; Hall, 1988). An example is the analysis of the genetic composition of the Africanized honeybee, the population of bees resulting from the introduction of Apis mellifera scutellata to Brazil in 1956 (Kerr, 1967; Michener, 1975). Estimation of the frequencies of some racial markers in these populations may reveal the existence or otherwise of interracial hybridization during the initial settlement of $A$. $m$. scutellata in Brazil, and its subsequent migration across the American continent Hall \& Muralhidharan, 1989; Lobo et al., 1989; Smith et al., 1989; Del Lama et al., 1990, Hall, 1990; Smith, 1991).

Apis mellifera populations are made up of families of numerous progeny, consisting of sterile workers descended from a queen mated with a mean of 17 drones in Africanized honeybees (Adams et al., 1977), whose spermatozoa are stored in a specialized organ (spermathecae). Eventually new queens are produced by trophic stimulation of some larvae, and new drones

*Correspondence. by arrenotokous parthenogenesis. Because of this, population samples are restricted to sterile workers (or eventually drones) collected from a limited number of hives, from which genetic parameters of reproductive individuals are estimated. In this sampling scheme, errors such as variance under-estimation can easily occur if a simple multinomial sampling of genotypes is assumed (cf. Fisher, 1940), especially when sample sizes vary between colonies.

Following Arnold (1981) and Arnold \& Morrison (1985), the general model which defines the probability of a genotypic vector in a progeny $(n)$ in terms of the genotypes of a cryptic paternity $(y)$ and an unknown vector of populational parameters $(\theta)$, will be

$\mathrm{p} r(n / \theta)=\Sigma_{y} \mathrm{p} r(n / y) \mathrm{p} r(y / \theta)$

which are simply the marginal probabilities of $n$ given each possible paternity $y$, weighted by the genotypic frequency of $y$.

Our objective is to adapt model (1) to the characteristics of reproduction and genetic structure of Apis mellifer $a$, in order to infer $\theta$ by maximum likelihood. Here, we will restrict this problem to the estimation of gene frequencies and admixture proportions, but the model developed could be easily modified for other purposes. 


\section{Segregation of drones}

The progeny of drones represent the segregation of the queen's gametes, because of their haploid constitution and parthenogenetic origin. Defining $n z$ as the vector of drone genotypes observed in a colony and $R$ as a queen genotype at a locus with $k$ alleles, the conditional probability $\mathrm{p} r(n z / R)$ could be easily deduced through a division of the sampling space of $n z$ : the event $Z_{i}$, all the drones with the same allele $i$, and the event $Z_{i, j}$, where two drone genotypes with alleles $i$ and $j$ are observed. Assuming no segregation distortion of the alleles of a heterozygote queen,

$\operatorname{pr}\left(n z=Z_{i} / R_{i i}\right)=\operatorname{pr}\left(n z=Z_{j} / R_{j j}\right)=1$,

$\operatorname{pr}\left(n z=Z_{i} / R_{i j}\right)=\operatorname{pr}\left(n z=Z_{j} / R_{i j}\right)=(1 / 2)^{n}$,

and

$\operatorname{pr}\left(n z=Z_{i, j} / R_{i, j}\right)=1-(1 / 2)^{n-1}$

where $n$ is the total number of drones sampled in the colony, and $R_{i i}, R_{i j}$ represent homozygous and heterozygous queens, respectively. Other events where a drone has an allele not present in $R$ would have zero probability. Morris \& Spieth (1978) used this approach to infer heterozygosity from female gametophytes in conifers.

\section{Segregation of workers}

Let us define no as the vector of worker genotypes sampled from a colony, $\left\{n_{l l}, \ldots, n_{k k}\right\}$, each element being the numbers of workers with a genotype containing subscript alleles. A particular value of no depends on $R$ and the fertilization frequency of the different male alleles stored in the spermathecae. This frequency depends not only on the number of matings with drones having a particular allele, but also on sperm competition events before and after copulations (Laidlaw \& Page, 1986; Page, 1986), and on the extent of mixing of the different ejaculates (Taber, 1955). Adams et al. (1977) and Cornuet et al. (1986) proposed a discrete distribution for these male gene frequencies, based on a binomial sampling from $n$ mated males, where $n$ follows a truncated Poisson distribution.

We prefer to use a more flexible continuous distribution, the Dirichlet distribution, as the density function of the fertilization frequencies of the male alleles stored in the population of spermathecae. This distribution, as a multivariate version of the beta distribution, is a convenient model of family segregation that follows binomial or multinomial sampling distributions with the probability of events varying from family to family (Skellam, 1948; Edwards, 1955; Morton, 1969).
Let us define $v$ as the vector of parameters of the Dirichlet distribution $\left(v_{1}, v_{2}, \ldots, v_{\mathrm{k}}\right), v_{i}$ being the parameter of the $i$ th allele. The $i$ th mean of this distribution, $v_{i} /\left(v_{1}+v_{2}+\ldots v_{k}\right)$, will be equal to $p_{i m}$, the populational male gene frequency of allele $i$. Given a queen genotype $R$ and a vector $v$, the conditional probabilities of no are obtained by integrating a multinomial function with elements defined by the respective row of the mother-daughter transition matrix (Li \& Stacks, 1955 ) over all possible values of the male fertilization frequencies, resulting in

$$
\begin{aligned}
\operatorname{pr}\left(n \mathrm{o} / R_{i i}, v\right)= & \left(\frac{n}{n \mathrm{o}}\right) \frac{\Gamma\left(v_{1}+\ldots+v_{k}\right)}{\Gamma\left(v_{1}\right) \ldots \Gamma\left(v_{k}\right)} \\
& \times \frac{\Gamma\left(v_{i}+n_{i i}\right) \prod_{j} \Gamma\left(v_{j}+n_{i j}\right)}{\Gamma\left(n+v_{1}+\ldots+v_{k}\right)}
\end{aligned}
$$

and

$$
\begin{gathered}
\operatorname{pr}\left(n \mathrm{o} / R_{i j}, v\right)=\left(\begin{array}{c}
n \\
n \mathrm{o}
\end{array}\right) \frac{\Gamma\left(v_{1}+\ldots+v_{k}\right)}{\Gamma\left(v_{1}\right) \ldots \Gamma\left(v_{k}\right)} \\
\frac{\left(\frac{1}{2}\right)^{n}\left[\sum_{x=0}^{n_{i j}}\left(\begin{array}{c}
n_{i j} \\
x
\end{array}\right) \Gamma\left(v_{i}+n_{i i}+x\right) \Gamma\left(v_{j}+n_{j j}+n_{i j}-x\right)\right]}{\Gamma\left(n+v_{1}+\ldots+v_{k}\right)} \\
\times \frac{\prod_{i} \Gamma\left(n_{i l}+n_{j i}+v_{l}\right)}{\Gamma\left(n+v_{1}+\ldots+v_{k}\right)},
\end{gathered}
$$

where $i, j, l=1, \ldots, k$ and $i \neq j \neq 1$.

Here $\left(\begin{array}{l}n \\ n o\end{array}\right)$ and $\left(\begin{array}{l}n_{i} \\ x\end{array}\right)$ are the multinomial and binomial coefficients, respectively, $n$ is the sample size, and $\Gamma(x)$ is the gamma function. Again, other events, where no contains genotypes with alleles not contained in $R$, have zero probability. In the case of only two alleles, terms with $l$ allele will disappear and the distribution of male gene frequencies will be a beta distribution. Finally, the joint probability of a sample of $n o$ and $n z$ progenies from a colony will be (omitting queen alleles for the sake of simplicity);

$$
\begin{aligned}
& \operatorname{pr} r\left(n \mathrm{o}, n z / p_{\mathrm{f}}, v\right) \\
& \quad=\sum_{R} \operatorname{pr} r\left(R / p_{\mathrm{f}}\right) \mathrm{p} r(n \mathrm{o} / R, v) \mathrm{p} r(n z / R)
\end{aligned}
$$

$p_{\mathrm{f}}$ being the female population vector frequencies and $\mathrm{p} r\left(R / p_{\mathrm{f}}\right)$ the genotypic queen frequencies, which could be defined in terms of the Hardy-Weinberg or some other model.

Noting the functional dependence between $v$ and $p_{\mathrm{m}}$, the vector of populational male gene frequencies 
(7) can be defined in terms of $p_{\mathrm{m}}$ and one element of $v$, e.g. $v_{1}$

$$
\begin{aligned}
& \operatorname{pr}\left(n \mathrm{o}, n z / p_{\mathrm{f}} p_{\mathrm{m}}, v_{1}\right) \\
& \quad=\sum_{R} \mathrm{p} r\left(R / p_{\mathrm{f}}\right) \mathrm{p} r\left(n \mathrm{o} / R, p m, v_{1}\right) \mathrm{p} r(n z / R) .
\end{aligned}
$$

A simpler version of $(8)$ would be a model with the condition $p_{\mathrm{f}}=p_{\mathrm{m}}=p$, i.e. equal gene frequencies between sexes.

\section{Racial admixture model}

In a tri-hybrid population, the frequency of the $i$ allele can be expressed as a linear function of ancestral gene frequencies and admixture proportions (Krieger et al., 1965). Lobo et al. (1989) proposed three honeybee races: Apis mellifera scutellata, Apis mellifera mellifera and Apis mellifera ligustica as the hypothetical ancestral races of the Africanized honeybee, based on historical reports (Nogueira-Neto, 1972). Therefore,

$p_{i}=S p_{i_{S}}+M p_{i_{M}}+L p_{i_{\ell}}$,

where $S, M$ and $L$ are the admixture proportions and $p_{i S}, p_{i M}, p_{i L}$ are the ancestral frequencies of the races scutellata, mellifera and ligustica, respectively. Function (9) can replace the elements of the vectors $p_{\mathrm{f}}$ and $p_{\mathrm{m}}$, thus expressing (8) as a function of the racial proportions.

Ancestral gene frequencies for these races are known for only two isoenzyme systems (MDH and HK), and two mitochondrial morphs (Smith et al., 1989; Hall and Muralhidharan, 1989). Here we will obtain estimates of racial admixture using isoenzyme data, whose ancestral gene frequencies are summarized in Table 1.

\section{Estimation of parameters}

The entire sample from a particular locality consists of a number of $n o$ and $n z$ vectors originating from differ- ent colonies. Sampling of these progenies can be seen as a sampling of multinomially distributed events ( $n o$, $n z)$ with probabilities $\mathrm{p} r(n \mathrm{o}, n z / \theta)$, and the maximum likelihood estimate of $\theta$ can be obtained by the standard procedures (Elandt-Johnson, 1971). Elements of the scores vector and information matrix were calculated in each iteration by using the general algorithm of Reed (1969), estimating first derivatives numerically. Convergence to the maximum likelihood estimates (MLE) was obtained easily in most cases.

Estimation of the racial admixture proportions using multiple loci and the model (8) followed the special algorithm suggested by Miki et al. (1969) to obtain MLE simultaneously of parameters within and between systems. The $v$ values in (8) define the distribution of male gene frequencies for each locus; they may be different between loci. Racial admixture proportions must be homogeneous between loci. Iterations were performed for each locus to obtain MLE of $v_{1}$ with fixed initial values of $S$ and $M$, after which the scores vector and the information matrix for $S$ and $M$ were summed up between systems, corrections terms for $S$ and $M$ were calculated and a new iteration process was repeated until convergence was achieved.

\section{Application to the analysis of Africanized samples}

To test the fit of the model, a sample of 206 colonies was taken from two neighbouring localities, Luiz Antonio and Matão, in São Paulo state, Brazil (sample 1-2 Table 2). Eight workers and eight drones were taken from each colony, a sample size chosen in order to avoid an excessively sparse distribution of segregation probabilities, which is inconvenient when a chisquared test of goodness of fit is applied. Genotypes for two isoenzyme systems, MDH (alleles A, B and C) and $\mathrm{ADH}$ (alleles 1,2 and 3), were scored in each individual using the standard starch gel electrophoresis procedures (Contel et al., 1977; Martins et al., 1977).

Table 1 Ancestral gene frequencies of the three hypothetical ancestral races of the

\begin{tabular}{|c|c|c|c|c|c|c|c|}
\hline \multirow[b]{2}{*}{ Race } & \multicolumn{4}{|c|}{ MDH alleles } & \multicolumn{3}{|c|}{ HK alleles } \\
\hline & A & B & $\mathrm{C}$ & Source & F & $\mathrm{S}$ & Source \\
\hline A. m. scutellata & 1.000 & - & - & 1 & 0.290 & 0.710 & 4 \\
\hline A. m. mellifera & 0.026 & 0.902 & 0.072 & 1 & 1.000 & - & 3 \\
\hline A. m. ligustica & 0.200 & 0.030 & 0.770 & 2 & 1.000 & - & 3 \\
\hline
\end{tabular}
Africanized honeybee

Sources: ${ }^{1}$ Nunamaker et al. (1984). ${ }^{2}$ Badino et al. (1983). ${ }^{3}$ Del Lama et al. (1988), Sheppard and Berlocher (1984). ${ }^{4}$ Smith et al. (1989). 
Table 2 Origin of the different Africanized honeybee samples analysed in the present study

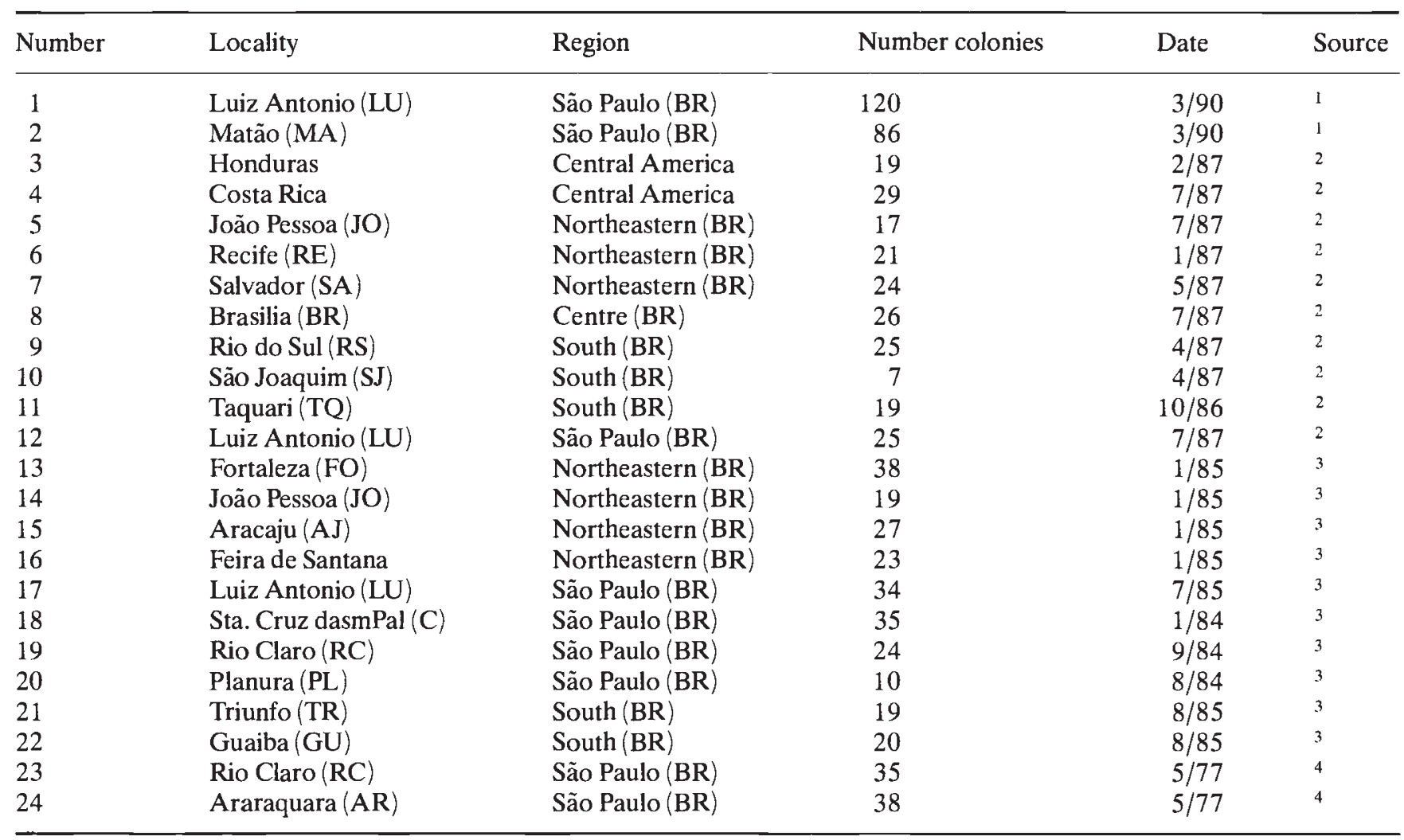

Sources: ${ }^{1}$ Present study, ${ }^{2}$ Del Lama et al. $(1990),{ }^{3}$ Lobo et al. (1989), ${ }^{4}$ Contel et al. (1977).

Special precautions to avoid sampling of colonies with laying workers were taken.

Other samples from the literature were chosen in order to re-evaluate gene frequencies of MDH system within Brazil (samples 5-24), or to estimate racial admixture proportions in samples where $\mathrm{MDH}$ and HK systems were scored (samples 3-11). All the samples analysed eight worker bees per colony, with the exception of samples 5, 23 and 24 (four workers). Table 2 gives the origin, date of collection and number of colonies for each locality.

Table 3 shows the distribution of the different values of $(n \mathrm{o}, n z)$ observed in the samples 1-2 for the systems $\mathrm{MDH}$ and $\mathrm{ADH}$, and the corresponding expected values from the model (8) (equal gene frequencies between sexes). Segregations with expected values less than 2 (including those with zero observations) were pooled. The distributions predicted by the model seem to fit the observed distributions well, although sample size is rather small to be conclusive. Fitting the model with unequal gene frequencies between sexes does not significantly improve the fit to the data: the respective likelihood ratio test was 0.69 for the $\mathrm{MDH}$ and 3.74 for the $\mathrm{ADH}$, with 2 d.f., giving no support for difference between sexes. MLE of the parameters in this sample were (subscript representing the respective allele): $p_{\mathrm{A}}=0.819 \pm 0.009, \quad p_{\mathrm{B}}=0.172 \pm 0.009, \quad p_{\mathrm{c}}=$ $0.009 \pm 0.002, v_{\mathrm{A}}=15.72 \pm 6.51$, for the $\mathrm{MDH}$ locus, and $p_{1}=0.233 \pm 0.011, p_{2}=0.736 \pm 0.012, p_{3} 0.031$ $\pm 0.004, v_{1}=2.46 \pm 0.641$ for the $\mathrm{ADH}$ locus.

Estimates of racial proportions in samples 3-11 are shown in Table 4. Estimates were obtained in each geographical region. Chi-squared of heterogeneity between systems was calculated using $\Sigma U_{i}^{\prime} K_{i}^{-1} U_{i}$, where $U_{i}$ and $K_{i}$ are the scores vector and information matrix, respectively, of the $i$ th locus for a joint estimated of $S$ and $M$. Differences between regions are evident, with increased mixing of European races in Central America and Southern Brazil, but with a constant predominance of scutellata gene flow. This result confirms the general pattern observed with information from only the MDH locus by Lobo et al. (1989) and Del Lama et al. (1990). A new element detected here is the significant heterogeneity between systems in the two Brazilian regions. Most of the heterogeneity $\chi^{2}$ came from the HK locus term in $U, K^{-1} U(4.13$ in the Southern region, 3.78 in the Centre-Northeastern region). The correction term $U^{\prime} K^{-1}$ for the $S$ parameter in this locus was -0.07 in Centre-Northeastern, -0.08 in the South and -0.05 in Central America. So 
Table 3 Progeny data from samples 1-2. Worker genotypes are shown below (no), drone segregations are represented in the column $(n z)$ (see text). Obs. refers to the number of colonies with the respective progeny and Exp. to the expected number according to model (8)

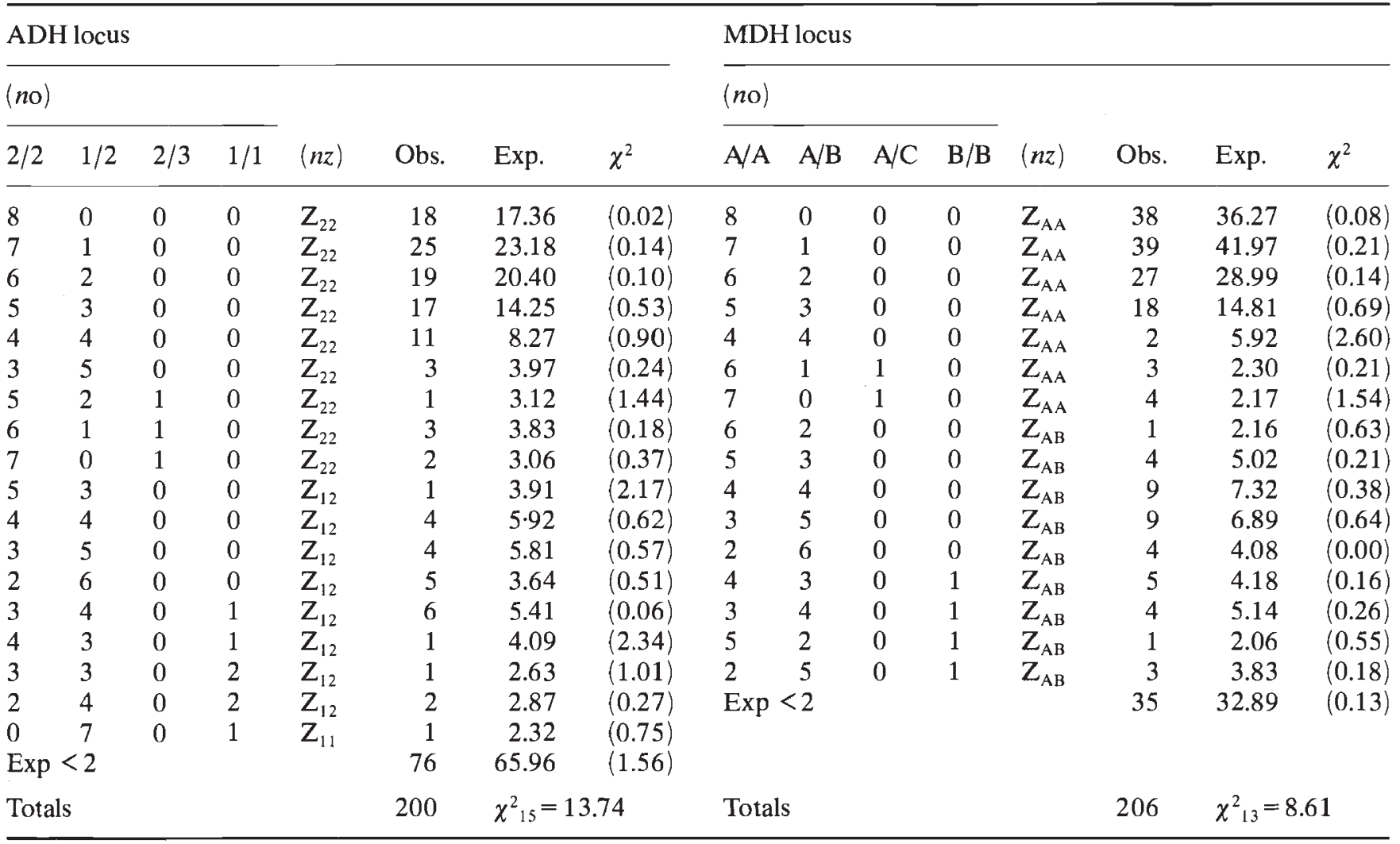

Table 4 Estimates of racial admixture in three regions of Africanized honeybee distribution

\begin{tabular}{llcc}
\hline & $\begin{array}{l}\text { Centre-Northeastern } \\
\text { Brazil } 88 \text { colonies })\end{array}$ & $\begin{array}{l}\text { South Brazil } \\
\text { (51 colonies) }\end{array}$ & $\begin{array}{c}\text { Central America } \\
\text { (48 colonies) }\end{array}$ \\
\hline Parameters within systems & & & $1.85 \pm 0.50$ \\
$\quad v_{\mathrm{A}}$ & $23.71 \pm 21.70$ & $2.29 \pm 1.18$ & $2.43 \pm 1.12$ \\
$\quad v_{\mathrm{F}}$ & $2.29 \pm 1.18$ & $2.45 \pm 1.80$ & \\
Parameters between systems & & & $0.636 \pm 0.038$ \\
$S$ & $0.853 \pm 0.033$ & $0.728 \pm 0.061$ & $0.165 \pm 0.042$ \\
$M$ & $0.144 \pm 0.035$ & $0.272 \pm 0.071$ & $0.199 \pm 0.030$ \\
$L$ & $0.003 \pm 0.013$ & $0.000 \pm 0.028$ & 2.60 \\
\hline$\chi_{\text {Het(1 d.f) }}^{2}$ & $4.64^{*}$ & $6.27^{* *}$ & \\
\hline
\end{tabular}

$\chi_{\text {Het }}^{2}=$ Heterogeneity chi-squared between systems.

the HK locus predicts a lower proportion of African admixture in relation to the $\mathrm{MDH}$ locus, this discrepancy being the source of the observed heterogeneity. Following the suggestions of Krieger et al. (1965), variances were multiplied by the square root of the mean square between systems (equal to the $\chi^{2} \mathrm{Het}$, in this case), in order to take into account the uncertainty of ancestral gene frequencies.
Finally, estimates of $p_{\mathrm{A}}$ frequency in the $\mathrm{MDH}$ locus, which is the MDH allele apparently fixed in Apis mellifera scutellata, are shown in Fig. 1 in relation to the latitude and year of collection of the Brazilian localities. A cline in $p_{\mathrm{A}}$ with latitude is observed with an apparant temporal increase in frequency in localities sampled twice (João Pessoa, Rio Claro and Luiz Antonio). To test this pattern, a multiple regression 


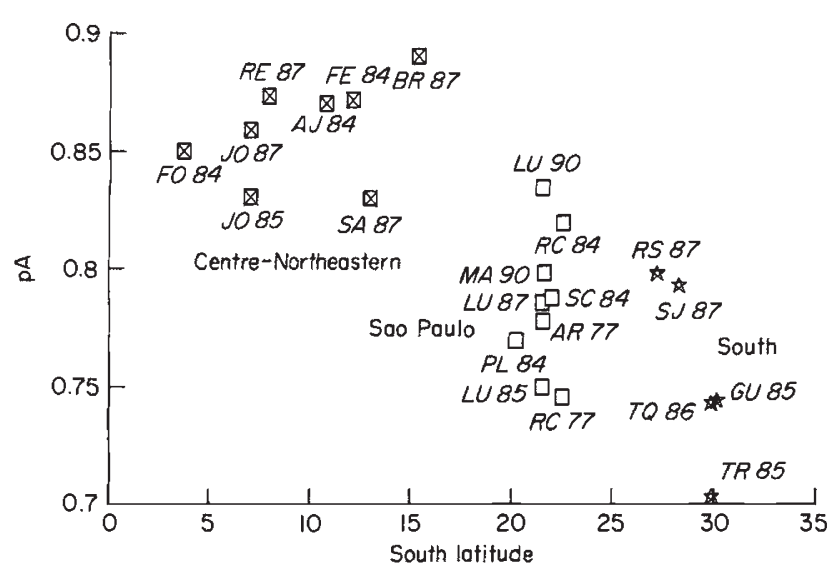

Fig. 1 Geographical and temporal variability of $\mathrm{MDH}$ allele $\mathrm{A}\left(p_{\mathrm{A}}\right)$ in Brazil. Locality and year of collection are indicated for each point in the figure (see Table 2).

analysis was performed for $p_{\mathrm{A}}$ frequency in Brazil, using degrees of South latitude and the year of collection [scaled from 0 (1977) to13 (1990)] as independent variables. Considering the heterogeneity of sample size, each point was weighed by the inverse of its variance. This model removed a significant amount of the variation $\left(F_{2,19}=16.0^{* *}\right)$; regression coefficients were $-0.00473 \pm 0.00087$ for latitude and $0.0038 \pm$ 0.0015 for the year of data collection.

\section{Discussion}

The estimates of Africanized honeybee gene frequencies and racial admixture presented here have a higher variance than past reports (Lobo et al., 1989; Del Lama et al., 1990), as a result of better weighting of the amount of information that each progeny gives about population gene frequencies. Therefore, hypothesis tests are more conservative, which is desirable.

Estimates of racial admixture give support to the existence of low but significant levels of gene flow from European races, with a small component of geographical heterogeneity. Evidence of this is the segregation in Africanized honeybee populations of typical European alleles, such as the $M$ allele of PGM (Sheppard \& Huettel, 1988) and $C$ allele of MDH (Contel et al., 1977). As has been already noted, precise estimates of racial admixture proportions are hardly ever obtained because of inevitable uncertainties in ancestral gene frequencies. This is the most probable cause of heterogeneity of racial mixture estimates between loci (Krieger et al., 1965; Adams \& Ward, 1973), as was observed in the estimates in this study. This is a common problem of isoenzyme and DNA restriction- site polymorphism studies. However, judging by the corrected standard errors of Table 4, the general picture of heterogeneity of European gene flow levels into Africanized honeybee populations, even into ones where pure European specimens have not been seen for many years, seems to be supported by isoenzyme data.

This hypothesis may explain the cline in $p_{\mathrm{A}}$ in Brazil where the recent introduction of European races is too scarce to influence natural Africanized honeybee populations. Due to the much higher viability and fertility of African bees in relation to European ones in a tropical and subtropical environment (Michener, 1975), the actual frequencies of Africanized genetic markers such as the ones studied here, could be the result of the initial admixture proportions and 'hitchhiking' of presumably neutral markers on adaptive alleles, due to the expected gametic disequilibrium in the first generations after racial mixture. During the initial phases of Africanized honeybee settlement, geographical heterogeneity of European bee density, as well as variability between regions of the selection coefficients which favour adaptative African genes, could have produced the cline observed in Fig. 1.

A cline like the one characterized above can be transitory because of the effect of migration, particularly long-distance migration. The apparent increase in $p_{\mathrm{A}}$ in some localities during the last 13 years may be a result of migration between regions, or of a very gradual transition to equilibrium frequencies after initial admixture and subsequent selection.

Hall (1990) reported very low frequencies of European alleles detected with nuclear DNA probes in pools of Africanized workers from different localities in Central and South America. The European alleles detected with these probes are very specific to the Apis mellifera ligustica race. This result does not therefore conflict with the isoenzyme data, which also revealed a very small gene flow from the Italian honeybee.

Smith et al. (1989), Hall and Muralhidharan (1989) and Arias et al. (1990) reported the fixation of the African mitochondrial DNA morph in Africanized populations. This is in apparent conflict with isoenzyme data, mainly in Central America, where mitochondrial data from Mexico (near to the migration front, as was the case in Honduras and Costa Rica on the respective dates of collection), reveal very low frequencies of the mitochondrial DNA morph of European races. Hall (1990) suggested the existence of asymmetry between sexes in the introgression of European genes during the Africanized honeybee expansion.

Hitchhiking of neutral markers on rapidly selected adaptive African genes, could, to some extent, explain 
the low levels of European admixture at the nuclear markers, even with an initial low density of African colonies. If colony performance is more influenced by the queen genotype than by the mated drone genotypes, this hitchhiking effect would have a stronger effect on the evolution of mitochondrial morph frequencies, which are maternally inherited. It could explain greater frequencies of nuclear European alleles than European mitochondrial morphs. This model supposes that the reproductive performance of colonies with hybrid workers and a European queen would be much lower than the reciprocal cross (African mother and European drones). Although there is evidence that hybrid colonies headed by European queens seem to show African patterns in defensive behaviour and daily activity (Kerr et al., 1972), viability and fertility parameters, mainly the swarming rate, which is strongly influenced by the queen, need to be compared between the two reciprocal crosses in order to test the validity of this model.

\section{Acknowledgements}

We wish to express our sincere thanks to the beekeepers that gave their assistance to the sampling of the bees used in this study. This work was supported by the following Brazilian agencies: CNPq, FINEP and CAPES and the Costa Rican Research Council (CONICIT).

\section{References}

ADAMS, J. AND WARD, R. H. 1973. Admixture studies and the detection of selection. Science, 180, 1137-1143.

ADAMS, J., ROTHMAN, E. D., KERR, W. E. AND PAULINO, Z. L. 1977. Estimation of the number of sex alleles and queen matings from diploid male frequencies in a population of Apis mellifera. Genetics, 86, 583-596.

ARIAS, M. C., SOARES, A. E. E. AND NóBREGA, F. G. 1990. Improvements to the mitochondrial restriction maps for Italian and Africanized honeybees. Rev. Bras. Genet., 13, 501-507.

ARNOLD, J. 1981. Statistics of natural populations. I: Estimating an allele probability in cryptic fathers with a fixed number of offspring. Biometrics, 37, 495-504.

ARNOLD, J. AND MORRISON, M. L. 1985. Statistics of natural populations. II. Estimating an allele probability in families descended from cryptic mothers. Genetics, 109, 785-798.

badino, G., Celebrano, G. AND manino, A. 1983. Population structure and MDH-1 locus variation in Apis mellifera ligustica. J. Hered. 74, 443-446.

CONTEL, E. P. B., MESTRINER, M. A. AND MARTINS, E. 1977. Genetic control and developmental expression of malate dehydrogenase in Apis mellifera. Biochem. Genet., 15, 859-876.

CORNUET, J. M., DAOUDI, A. AND CHEVALET, C. 1986 . Genetic pollution and number of matings in black honey bee. Theor. Appl. Genet., 73, 223-227.
DEL LAMA. M. A., FIGUEREIDO, R. A., SOARES, A. E. E. AND DEL LAMA, S. N. 1988. Hexoquinase polymorphism in Apis mellifera and its use for Africanized honeybee identification. Rev. Bras. Genet. 11, 287-297.

DEL LAMA, M. A., LOBO, J. A., SOARES, A. E. E., AND DEL LAMA, S. N. 1990. Genetic differentiation estimated by isozymic analysis of Africanized honeybee populations from Brazil and from Central America. Apidologie, 21, 271-280.

EDWARDS, A. W. F. 1959. Some comments on Schützenberg's analysis of data on the human sex ratio. Ann. Hum. Genet, 24, 233-238.

Elandt-JOHnson, R. 1971. Probability Models and Statistical Methods in Genetics. John Wiley \& Sons. New York.

FISHER, R. A. 1940. The estimation of the proportion of recessives from tests carried out on a sample not wholly unrelated. Ann. Eugen., 10, 160-170.

HALL, H. G. 1988. Characteristics of the African honeybee genotype by DNA restriction fragments. In: Needham, G. R., Page, R. E., Delfinado-Baker, M. and Brown, C. E. (eds) Africanized Honeybees and Bee Mites, Ellis Horwood, Chichester, pp. 287-293.

HALL, H. G. 1990. Parental analysis of introgressive hybridization between African and European honeybees using nuclear DNA RFLPs. Genetics, 125, 611-621.

HALL, H. G. AND MURALIDHARAN, K. 1989. Evidence from mitochondrial DNA that African honeybees spread as continuous maternal lineages. Nature, 339, 211-213.

KERR, W. E. 1967. The history of the introduction of African bees to Brazil. South Afric. Bee J., 39, 3-5.

KERR, W. E., GONÇALVES, L. S., BLOTTA, L.F., AND MACIEL, H. B. 1972. Biologia comparada entre as abelhas italianas (Apis mellifera ligustica) africana (Apis mellifera adansonii) e suas hibridas. I Congresso Brasileiro de Apicultura. Florianópolis, 1970.

KRIEGER, H., MORTON, N. E., MI, M. P., AZEVEDO, E., FREIRE-MAIA, A., AND YASUDA, N. 1965. Racial admixture in north-eastern Brazil. Ann. Hum. Genet., 29, 113-125.

LAIDLAW, H. H. AND PAGE, R. E. 1984. Polyandry in honeybees (Apis mellifera L.): sperm utilization and intracolony genetic relationships. Genetics, 108, 985-997.

LI, C. C. AND STACKS, L. 1955. The derivation of the joint distribution and correlation between relatives by the use of stochastic matrices. Biometrics, 10, 347-360.

Lobo, J. A., Del LamA, M. A. AND Mestriner, M. A. 1989. Population differentiation and racial admixture in the Africanized honeybee (Apis mellifera L.). Evolution, 43, 794-802.

MARTINS, E., MESTRINER, M. A. AND CONTEL, E. P. B. 1977. Alcohol dehydrogenase polymorphism in Apis mellifera. Biochem. Genet., 15, 357-365.

MICHENER, C. D. 1975. The Brazilian bee problem. Ann. Rev. Entomol., 20, 399-416.

MIKI, C., YEE, S., YASUDA, N., AND MORTON, N. E. 1969. Alltype. In: Morton, N. E. (ed.) A Genetic Program Library, University of Hawaii Press, Honolulu, pp. 24-28.

MORRIS, R. W. AND SPIETH, P. T. 1978. Sampling strategies for using female gametophytes to estimate heterozygosity in conifers. Theor. Appl. Genet., 51, 217-222.

MORTON, N. E. 1969. Segregation analysis. In: Morton, N. E. 
(ed.) Computer Applications in Genetics, University of Hawaii Press, Honolulu, pp. 129-139.

NOGUEIRA-NETO, P. 1972. Notas sobre a historia da apicultura brasileira. In: Camargo, J. M. F. (ed.) Manual de Apicultura, Agron. Ceres, São Paulo, Brazil, pp. 96-115.

NUNAMAKER, R. A., WILSON, W. T. AND HALEY, B. E. 1984. Electrophoretic detection of Africanized honeybees (Apis mellifera scutellata) in Guatemala and Mexico based on malate dehydrogenase allozyme patterns. J. Kansas Entomol. Soc., 57, 662-631.

PAGE, R. E. 1986. Sperm utilization in social insects. Ann. Rev. Entomol., 31, 297-320.

REED, T. E. 1969. Genetic experiences with a general maximum likelihood estimation program. In: Morton, $\mathrm{N}$. E. (ed.) Computer Applications in Genetics, University of Hawaii Press, Honolulu, Hawaii, pp. 27-29.

SHEPPARD, W. S. AND BERLOCHER, S. H. 1985. New allozyme variability in Italian honeybees. J. Hered., 76, 45-48.

SHEPPARD, W. S. AND HUETTEL, M. D. 1988. Biochemical genetic markers, intraspecific variation, and population genetics of the honeybee, Apis mellifera. In: Needham, G. R., Page, R. E., Delfinado-Baker, M. and Brown, C. E. (eds) Africanized Honeybees and Bee Mites, Ellis Horwood, Chichester, pp. 281-286.

SKELlAM, J. G. 1948. A probability distribution derived from the binomial distribution by regarding the probability of success as variable between the sets of trials. $J$. R. Stat. Soc. B 10, 257-261.

SMITH, D. R. 1991. African bees in Americas: insights from Biogeography and Genetics. Trends Ecol. and Evol., 6 , 17-21.

SMITH, D. R., TAYLOR, O. R. AND BROWN, W. M. 1989. Neotropical Africanized honeybees have African mitochondrial DNA. Nature, 339, 213-215.

SYLVESTER, H. A. 1986. Biochemical genetics. In: Rinderer, T. E. (ed.) Bee Genetics and Breeding, Academic Press, New York, pp. 177-203.

TABER, S. 1955. Sperm distribution in the spermathecae of multiple-mated queen honeybees. J. Econ. Entomol., 48, $522-525$ 